\title{
Principles and methods of non-contact DC contactors calculation for alternative power systems
}

\author{
A. Soskov \\ O.M. Beketov National University of Urban Economy \\ in Kharkiv, \\ Ukraine \\ E-mail: ansoskov@gmail.com \\ O. Iegorov \\ O.M. Beketov National University of Urban Economy \\ in Kharkiv, \\ Ukraine \\ E-mail: diaskk67@gmail.com
}

\begin{abstract}
It is shown that the principle of control and power supply of a non-contact bi-directional DC contactor by the electrical line voltage is implemented by connecting the electronic control circuit by one output between two opposite powered gate-controlled thyristors of the bilateral switch to the first pole of the contactor and the second one - to the output clamp. As a result, the electrical line voltage is fed to the electronic circuit only for a short time (up to ms), that is determined by the charge time of the switching capacitor to the breakdown voltage of the threshold zener diode.
\end{abstract}

The peculiarities of the heating process of the power semiconductor contactor in different operating conditions were determined, that allowed to develop a methodology that with sufficient accuracy determines such important parameters as rated and operational current of the contactor.

In addition, it was found that in order to reduce significantly the capacity of the switching capacitor, and consequently the size and cost, it is necessary while turning on of the switching thyristor the discharging current of the switching capacitor was equal to the current of its charging circuit, and their values should not be less than the maximum allowable current of turning off the gate-controlled thyristor. It is allows to define justified the parameters of the elements that provide a secure turning off the bilateral switch.

The researches have also shown that the non-contact contactors due to the introduction of the network voltage control as compared with existing ones have peculiarities which rise competitive abilities. In particular, they are more reliable, they do not need to supply an additional power source, they exclude standard drivers, and minimize energy consumption.

Thus, an exemplary aspect of using the obtained scientific result is the ability to create competitive reliable non-contact DC contactors for voltage up to $1000 \mathrm{~V}$ and currents of 100600 A for alternative energy.

Key words - non-contact bi-directional DC contactor, switching capacitor, switching thyristor, power semiconductor switch, alternative energy

\author{
Ya. Forkun \\ O.M. Beketov National University of Urban Economy \\ in Kharkiv, \\ Ukraine \\ E-mail: jana.forkun@gmail.com \\ M. Glebova \\ O.M. Beketov National University of Urban Economy \\ in Kharkiv, \\ Ukraine \\ E-mail: marinaglebova34@gmail.com
}

\section{INTRODUCTION. THE RELEVANCE OF WORK AND TARGET SETTING}

In non-contact DC contactors, a non-contact electronic switch, as a rule, fully controlled power semiconductor device is typically used to provide an arc less commutation of the electrical circuits. The absence of an electric arc during the switching of load circuits, a high level of performance, and the absence of moving mechanical parts significantly improves the switching characteristics of these contactors compared with traditional contact devices [1].

However, their relatively high cost and size, compared to the latter ones, limit their area of usage. Therefore, it is advisable to use such devices in difficult operating conditions, such as frequent starting of electric engines, their reverse, in «smart» networks (Smartqreed) with alternative sources of electricity to switch their configuration, in explosive and fire hazardous environments and in other situations, where above mentioned advantages are determinative $[1,2]$.

It should be noted that nowadays, the use of DC semiconductor switching devices (including contactors) has significantly expanded due to the development of DC networks that use renewable electricity sources (solar and wind power) $[3,4]$.

In this regard, the works aimed at developing new principles for the creating non-contact switching devices and the methods of their calculation, that provide the solution of problem, which is related to increase their competitiveness in the world market of electric products, are relevant and in demand. It is confirmed by the results of a recent literature review cited by the authors in [2], which shows that similar works are being done around the world. $[4,5,6]$

\section{THE PURPOSE AND OBJECTIVES OF THE STUDY}

The purpose of the work is to create principles and methods for calculating the operating duties of non-contact DC contactors for alternative energy systems. 
To achieve the goal of the work, the following tasks must be solved:

- to investigate by analyzing that the principle of control and power supply of a bi-directional DC contactor circuit by the electrical line voltage allows to create qualities that increase its competitiveness in comparison with existing contactors;

- to carry out research of non-stationary electromagnetic and thermophysical processes in the noncontact contactor circuits and to develop the missing methods of calculation of these processes.

\section{TECHNICAL SOLUTIONS FOR THE NON-CONTACT DC CONTACTORS COMPOSED FOR ALTERNATIVE POWER SYSTEMS AND THEIR ANALYSIS.}

At O.M. Beketov National University of urban economy in Kharkiv (Ukraine, Kharkiv) developed technical solutions, which were presented in the form of two variants of electrical circuits of bi-directional noncontact DC contactors with control and power supply of electronic control circuit from the electrical line voltage. This principle and its implementation are protected by the patents $[7,8]$.
The first (main) variant of the contactor designed to perform frequent switching in alternative electrical systems is shown in figure 1.

In the circuit, such contactor elements as a bilateral fully controlled power semiconductor switch containing two opposite powered VS1 and VS2 gate-controlled thyristors with $V D 1$ and $V D 2$ freewheeling diodes, $M R 1$ current relay form its main circuit. Magnetically operated contacts (hermetic contacts) are used as $M R 1.1$ contacts of the current relay. $R 1$ resistor (block of varistors) and $V D 4, V D 9$ diodes are designed to dissipate the inductance energy stored in the network, and $V D 3$ and VD10 free-wheeling diodes to dissipate the load inductance energy at current interruption.

The $R 5$ charging resistor and the VS4 charging thyristor are designed to charge the $C 1$ switching capacitor. Such elements as closing contacts of the "Start" button, breaking contacts of the "Stop" button, VD5, $V D 8$ diodes and $R 2$ resistor form the circuit of the bilateral switch, and the $C 1$ switching capacitor, the $V S 3$ switching thyristor and the $R 3$ clipping resistor form the circuit of its release.

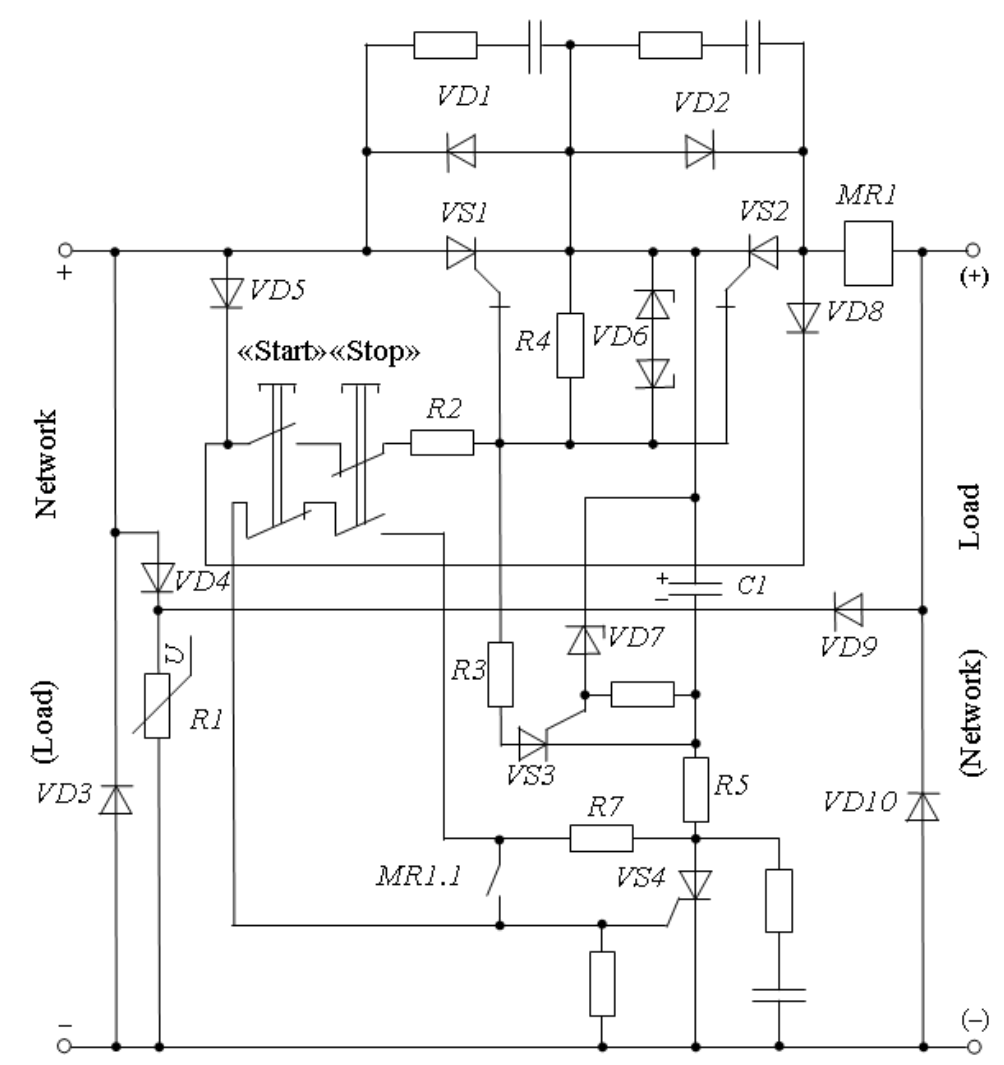

Fig. 1. Electrical circuit of the first variant of the non-contact bi-directional DC contactor

The breaking contacts of the "Start" button, the closing contacts of the "Stop" button and the $R 5$ resistor form the connection circuit of the VS 3 charging thyristor, which provides the charge of the switching capacitor.

The VD7 threshold zener diode limits the voltage on the switching capacitor at a given level, and the VD6 bidirectional voltage limiter and $R 4$ resistor protects the input of the bilateral switch from overvoltage during switching the contactor. The closing contacts of the $M R 1.1$ current relay ensure that the contactor will be released when the current of its power circuit of a given level is exceeded.

The principle of control and power supply of the electronic control circuit from the electrical line voltage is 
A. Soskov, Ya. Forkun, O. legorov, M. Glebova Issue 57, Vol. 01.

implemented in this contactor by connecting one lead of the $C 1$ switching capacitor between the cathodes of the $V S 1$ and VS 2 thyristors, and the second one through the $R 1$ charging resistor and the VS4 charging thyristor to the output terminal of the second contactor pole.

Due to this original connection, the circuit control elements are loaded just for a short time (up to $1 \mathrm{~ms}$ ) only when the contactor is turned on by the «Start» button and when it is turned off by the Stop button. In the on and off states of the contactor, all elements of the specified circuit are de-energized.

When using the programmable controller for control the contactor, the controller acts as the "Start" and "Stop" buttons. In this case, there are conditions for the creating substantially any automated duties of the contactor operation, that naturally extends its functionality.

A detailed description of the contactor operation and its features are given in [7].

The electrical circuit of the second variant of the bidirectional non-contact DC contactor is shown in figure 2. This contactor is different from the one studied above and not only reliably commutes bi-directional electricity flows, but is also successfully used in reverse-turn-on the electric engines with possible power recovery into the network.

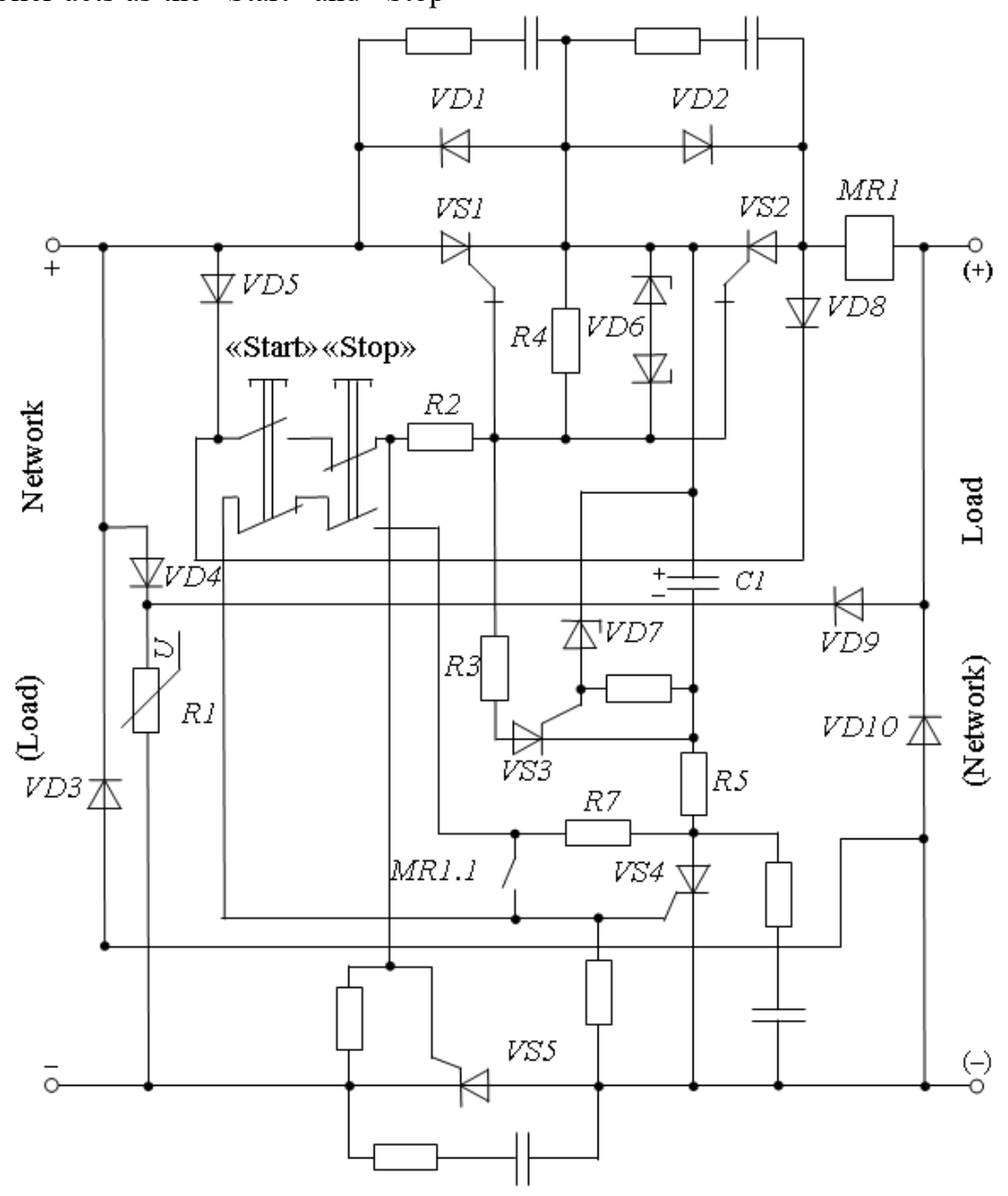

Fig. 2. The electrical circuit of the second variant of the bi-directional non-contact DC contactor

To provide the specified expansion of the functions into its main circle the VS5 power silicon controlled thyristor is additionally introduced. Its starting is ensured with starting power bilateral switch on the additional inserted circuit, namely $V D 11$ diode and $R 7$ resistor (Fig. 2). In addition, this contactor instead of free-whelling diodes which provide dissipation of load inductivity energy, has VS6 optron thyristor with VD3 and VD10 dividing diodes, whose input circuit is inserted in the discharge circuit of the switching capacitor (Fig. 2). Turning off the VS5 power thyristor occurs naturally when closing the bi-directional semiconductor switch.
Thus, the additional introduction of these elements provides the possibility of applying the second variant in reversible switching schemes, since the specified significantly increases its cost and size. This option is advisable to apply only in this narrow area, while the simpler first variant is applied in all other areas.

As follows from the above mentioned and the analysis presented in $[2,7,8]$, the technical solutions offered by the authors allow to create non-contact DC contactors, which in comparison with the existing ones have the following additional positive properties: 
- thanks to the adopted original technical solutions provide reliable arc less switching of bi-directional current in the network, as at turning the contactor on as its switching-off, at reduced size and cost of the product;

- have a modification suitable for use in reverse circuits;

- eliminate the necessity of using for commutation bilateral semiconductor switch of the high-value and dimensional drivers with a special power source;

- do not need an auxiliary power supply;

- have an economical operating mode of the electronic control circuit components, because they are under the load only while commutating the bilateral switch, that is, for up to a millisecond, and for a long time during the on and off state of the contactor, they are practically in storage mode, that significantly increases the reliability of the contactor operation (it is common knowledge that the failure rate of electronic components under the load is several times higher than that of non-loaded components);

- the voltage on the switching capacitor while commutating does not depend on either the voltage of the network or the switching current of the circuit, but is determined only by the value of the breakdown voltage of the threshold zener diode, that turn on the switching thyristor and is usually set at a safe for operation of the control circuit levels of 20-30 V.

It significantly increases the competitiveness of the offered contactors by improving operational performance and simplification of the production.

In order to ensure the practical implementation of the results obtained in this section, it is necessary to carry out studies of the processes that occur in the contactor circuits during the load switching, as well as to develop the necessary calculation methods based on the general patterns or to recommend existing ones.

\section{INVESTIGATION OF THE PROCESSES THAT OCCUR IN THE CONTACTOR CIRCUITS DURING LOAD SWITCHING AND DEVELOPING METHODS OF THEIR CALCULATION}

Non-contact DC contactors can operate under the following duties [1]:

- uninterrupted;

- uninterrupted with short-time overload;

- temporary;

- intermittent.

The current overload capacity of power semiconductor switches (PSSs) is determined by the maximum permissible temperature of the semiconductor structure $T_{V j \max }$, which should not be exceeded in various contactor duties.

It should be noted that the thermal regime of PSSs is the main factor that determines both the size and the cost of the device, and the level of its reliable operation $[1,9]$. In general, the thermal state of the PSS is determined by the nature of the current load (power) that affects the device and its design. In non-contact contactors PSSs are usually exposed to direct current (power). Therefore, the calculated ratios that determine their overload capacity by power, will be the following:

- permissible loss power in the uninterrupted duty

$$
P_{T \max }=\frac{T_{V j \max }-T_{a}}{R_{t h(j-c)}},
$$

where $T_{a}$ - ambient temperature;

$R_{t h(j-c)}$ - transient thermal resistance PSS transitionambient with a typical cooler, which adopted in the cooling system;

- permissible loss power in the uninterrupted duty with the following overload:

$$
P_{T \max }=\frac{T_{V j \max }-T_{a}-P_{T} \cdot P_{t h(j-c)}}{Z_{t h(j-c) n}}+P_{T},
$$

where $Z_{t h(j-c) \tau n}$ - transient thermal resistance transitionambient at the end of overload;

$P_{T}$ - power in the previous uninterrupted duty;

- permissible power in the temporary duty:

$$
P_{T \max }=\frac{T_{V j \max }-T_{a}}{Z_{t h(j-c) i}}
$$

where $Z_{t h(j-c) i}$ - transient thermal resistance transitionambient at the end of the pulse duration $t_{i}$;

- permissible loss power in the intermittent duty:

$P_{T \max }=\left(T_{V j \max }-T_{o m}\right) \cdot$

$\cdot \frac{1}{\frac{t_{n} R_{t h(j-c)}}{T}+\left(1-\frac{t_{n}}{T}\right) Z_{t h(j-c) T+t_{i}}-Z_{t h(j-c) T}+Z_{t h(j-c) t_{i}}}$,

where $t_{i}-$ pulse duration;

$T$ - duration of one cycle (period);

$R_{t h(j-c) T+t_{i}}, Z_{t h(j-c) T}, Z_{t h(j-c) t_{i}}$ - transient thermal resistance at the appropriate time.

Currently in the catalogs for modern fully controlled PSS analytical expression to determine, their transient thermal resistance is the following:

$$
Z_{t h(j-c)}(t)=\sum^{n} R_{i} \cdot\left(1-e^{\frac{-t}{\tau_{i}}}\right)
$$

where $R_{i}(K / k w)$ та $\tau_{i}(s)$ - the appropriate coefficients that are set up for each complement;

$n$ - number of complements (usually $n=4$ ).

In the case of impact on the PSS contactor the power impulse of an arbitrary form $P(t)$, overtemperature of its 
A. Soskov, Ya. Forkun, O. legorov, M. Glebova Issue 57, Vol. 01.

semiconductor transition $\theta$ at the end of the pulse is determined with known dependence of the transient thermal resistance (5) using the Duhamel integral:

$$
\theta=\int_{0}^{t_{i}} Z_{t h(j-c)} \cdot\left(t_{i}-\tau\right) \cdot \frac{d P(\tau)}{d \tau} d \tau
$$

As shown in [1], the main source of heating the semiconductor structure of PSS in non-contact contactors is the loss in the state of direct conductivity:

$$
P=I \cdot U_{(T 0)}+I^{2} \cdot r_{T},
$$

where $U_{(T 0)}$ and $r_{T}$ - threshold voltage and differential resistance of PSS;

$I$ - current through the device.

Or a refined formula:

$$
P=I \cdot\left[A_{T V j}+B_{T V j}+C_{T V j} \ln (I+1)+D_{T V j} \sqrt{I}\right],
$$

where $A_{T V j}, B_{T V j}, C_{T V j}$ та $D_{T V j}$ - coefficients provided by the PSS manufacturer for each type.

The calculations made by formulas (7) and (8) show that the results of formula (7) are higher than those of formula (8) and approach to the limit values. Therefore, the authors recommend to use the formula (7) only.

Substituting (7) into (1), (2), (3), (4), we obtain the equation to determine the ampacity of the SPC under different duties of the contactor:

- in the uninterrupted duty -

$$
I_{2}^{2} \cdot \tau_{T}+I \cdot U_{T 0}-\frac{T_{V j \max }-T_{a}}{R_{t h(j-c)}}=0
$$

- in the uninterrupted duty with the subsequent overload -

$$
\begin{aligned}
& I^{2} \cdot \tau_{T}+I \cdot U_{T 0}- \\
& -\frac{T_{V j \max }-T_{a}-P_{T} R_{t h(j-c)}}{Z_{t h(j-c)}}-P_{T}=0
\end{aligned}
$$

- in the temporary duty -

$$
I^{2} \cdot \tau_{T}+I \cdot U_{T 0}-\frac{T_{V j \max }-T_{a}}{Z_{t h(j-c) t n}}=0
$$

- in the intermittent duty -

$$
I^{2} \cdot \tau_{T}+I \cdot U_{T 0}-\left(T_{V j \max }-T_{a}\right) \text {. }
$$

1

$$
\overline{\frac{t_{n} R_{t h(j-c)}}{T}+\left(1-\frac{t_{n}}{T}\right) Z_{t h(j-c) T+t_{i}}-Z_{t n(j-c)}+Z_{t h(j-c) t_{i}}}=
$$$$
=0 \text {. }
$$

Based on the obtained equations for the type currently selected fully controlled PSS the rated current and the rated operating current of the apparatus are determined, and its overload current characteristic is expressed $\left(t_{\Pi}=f\left(\frac{I}{I_{\text {ном }}}\right)\right)$, that assist to find out maximum reload time.

Rated current characterizes the operation of the contactor in the uninterrupted duty, the rated operating current - in the intermittent duty. In the latter case, the electric engine usually acts as a load of the apparatus.

Contactor current:

- nominal

$$
I_{\text {ном }}=k_{3} \cdot I \text {, }
$$

where $k_{3}<k_{H} \cdot k_{n}$-depredation factor,

$k_{H}$ - a reliability factor that is recommended to be equal $0,9[1]$;

$k_{n}$ - a factor that takes into account the degree of current reduction with the possibility of prolonged operation of the device at the sustaining current $\left(I_{n o p}\right)$ of the maximum current protection operation $\left(I_{\text {пор }}=1,3 \cdot I_{\text {ном }}\right)$;

- nominal operating -

$$
I_{\text {номр }}=\frac{k_{3} \cdot I_{\partial n \kappa}}{k},
$$

where $I_{\partial n \kappa}-$ contactor current (allowable current value) in the intermittent duty;

$k$ - the starting current ratio of the DC engine.

The research of the operating hybrid and non-contact protection and control devices has shown that the most acceptable value $k_{3}$ is in the range from 0.55 to 0.60 [1].

Overload characteristic of the device on current $t_{\Pi}=f\left(\frac{I}{I_{\text {ном }}}\right)$ is set up according to the equation (10), and it always must pass above the protective maximum current characteristic.

Thus, the offered method of calculating the thermal duty of the PSS non-contact DC contactors which operate in the uninterrupted duty allows to determine the following important parameters and elements of the contactor, namely - rated current, rated operating current, types of PSS, as well as the overload characteristics in the current, that is, to evaluate almost fully its technical capability, and to a large extent to evaluate its size and cost indicators.

The calculation method of the switching over-voltages of the varistor over-voltage limiter, as well as the conditions for the choice of PSS in voltage were 
developed by the authors earlier and presented in [1]. It has been shown that the using a series-parallel connection of low-cost and small-sized and low-power varistors is possible to provide the level of switching voltages not higher than $(1,8 \div 2,0) \cdot U_{\text {ном }}$ at the rated currents of the contactor from 100 to $630 \mathrm{~A}$ and the electrical line voltage up to $1000 \mathrm{~V}$. [1].

The calculation method of the elements of the contactor control circuit with voltage control of the network is developed and its results are given in [2].

It was found that to significantly reduce the capacitance of the switching capacitor, and therefore its size and cost, it is necessary that while switching the thyristor the discharge current of the commuting capacitor is equal to the current in its charge circuit and its values should be not less than the maximum permissible closing current of the gate-controlled thyristor.

In $[1,2]$, relevant experimental researches were carried out, confirming the required accuracy of the offered calculation methods. Therefore, in the work there is no need for additional experimental studies.

Thus, the results of the studies presented in this section provide a practical implementation of the creation of the non-contact DC contactors with the previously stated positive properties.

\section{CONCLUSIONS}

1. It is substantiated that the offered non-contact contactors due to the introduction of technical solutions offered by the authors in comparison with the existing ones have the following advantages:

- have increased reliability due to the economical operation of the components of the electronic control circuit. Because they are only under the switching moment of the bilateral switch, that is, for up to a millisecond, under the load and for a long time, during the on and off state of the contactor, are practically in the storage mode, that significantly increases the reliability of the contactor operation (it is well known that failure rate of electronic components under the load, are several times larger than unloaded elements);

- the voltage on the switching capacitor during the switching process does not depend on either the voltage of the network or the switching current of the circuit, and is determined by the value of the breakdown voltage of the zener diode, which power up the switching thyristor, and is set at the safe level for control circuit operation at 20$30 \mathrm{~V}$;

- for closing the bilateral switch, the energy of the noncommuting capacitor is mainly used, and the energy of the network, due to the fact that the moment of its activation fulfills the condition under which the discharge current of the commuting capacitor and its charging current are equal to each other and will be no larger than the maximum allowable switch closing current, that naturally reduces the size and cost of the commuting capacitor;

- eliminates the need to use cost standard drivers and auxiliary power supplies;

- have a modification suitable for use in reverse circuits.

2. The results of the analysis of the offered technical solutions and the developed methods of calculating the contactor elements and its operating duties confirm the real possibility to create competitive non-contact DC contactors for alternative power systems for currents from 100 to $630 \mathrm{~A}$ and up to $1000 \mathrm{~V}$.

\section{REFERENSES}

[1] 1. Soskov, A. G. Improved power switching semiconductor devices of low voltage [Text]: monograph / A. G. Soskov; Hark. nat. Acad. Moscow. gos va. - Kh.: KNAGH, 2011. - 156 p.

[2] 2. B. Principles of constructions, calculation methods of direct current hybrid contactors for alternative energy / A. Soskov, Ya. Forkun, S. Kotelevets // Lighting engineering and power engineering. - 2019. - Vol.1 . - P. 18-29.

[3] 3. Yang Gao, Xiaoguang Wei, Zhiyuan He, Longlong Chen, Yunhai Shan. A hybrid circuit breaker for DC-application. IEEE First International Conference. - 2015. - P. 187 - 192, doi: 10.110 /ICDCM.2015.7152036.

[4] 4. Y. Sato, Y. Tanaka, A. Fukui, , M. Yamasaki, O. Hiromichi.An investigation of SiC-SIT DC circuit breakers for higher voltage direct current distribution systems. Energy Conversion Congress and Exposition (ECCE), 2010 IEEE. - 2010. - P. 3290-3295, doi: 10.1109/ECCE.2010.5617760.

[5] 5. Hassanpoor, A.; Hafner, J.; Jacobson, B. Technical Assessment of Load Commutation Switch in Hybrid HVDCBreaker. Power Electronics, IEEE Transactions on Year: 2015, Volume: 30, Issue: 10 Pages: 5393 - 5400.

[6] 6. Tanaka, Y. Development of semiconductor switches (SiCBGSIT) applied for DC circuit breakers [Text] / Y. Tanaka; A. Takatsuka, T. Yatsuo, Y. Sato, H. Ohashi // Electric Power Equipment - Switching Technology (ICEPE-ST), 2013 2nd International Conference. - 2013. P.1-4 DOI: 10.1109/ICEPEST.2013.6804323.

[7] 7. Paten. 134585. Non-Contact bi-directional DC Contactor (Soskov AG, Sabalaeva NO) Application u 2018 12490, Date of application 17.12.2018, Date of patent validity 27.05.2019, Bul. № 10.

[8] 8. Patent 101893 Non-Contact DC contactor (AG Soskov, ML Glebova, NO Sabalaeva, YB Forkun) application u 201501961 , application date 04.03.2015, patent effective 12.10.2015, bul. № 19 .

[9] 9. Voronin P.A. Power semiconductor switches: families, specifications, applications. Ed. 2nd rev. and add. - Moscow, 2005. -384 p. 
Принципи та методи розрахунку безконтактних контакторів постійного струму для систем альтернативної електроенергетики

\author{
А.Г. Сосков \\ Харківський національний університет міського \\ господарства ім. О.М.Бекетова, \\ Україна, \\ О.Б. Єгоров \\ Харківський національний університет міського \\ господарства ім. О.М.Бекетова, \\ Україна
}

\author{
Я.Б. Форкун \\ Харківський національний університет міського \\ господарства ім. О.М.Бекетова, \\ Україна \\ М.Л. Глєбова \\ Харківський національний університет міського \\ господарства ім. О.М.Бекетова, \\ Україна
}

\begin{abstract}
Показано, що принцип керування та живлення напругою мережі безконтактного двонапрямного контактора постійного струму реалізовано шляхом підключення електронної схеми керування одним виводом між двома зустрічно включеними силовими двоопераційними тиристорами двонапрямного ключа першого полюса контактора, а другим до вихідного затискача другого полюса. В результаті напруга мережі подасться на електронну схему тільки на короткий проміжок часу (до мс), який визначасться значенням часу заряду комутуючого конденсатора до напруги пробою порогового стабілітрона.
\end{abstract}

Визначені особливості процесу нагріву силових напівпровідникових контакторів в різних режимах його роботи, що дозволило розробити методику, що з достатньою точністю визначає такі важливі параметри як номінальний та робочий струм контактора.

Крім цього, було встановлено, що для суттєвого зменшення смності комутуючого конденсатора, а відповідно і габаритів та вартості, необхідно, щоб в момент включення комутуючого тиристора розрядний струм комутуючого конденсатора дорівнював струму його зарядного кола, а їх значення не повинні бути меншими ніж максимально допустимий струм запирання двоопераційного тиристора. Це дозволяс обгрунтовано підходити до визначення параметрів елементів, що забезпечують надійне запирання двонапрямного ключа.

В результаті проведених досліджень також було показано, що пропоновані безконтактні контактори завдяки введенню керування напругою мережі у порівнянні 3 існуючими мають властивості, що підвищують конкурентоспроможність. Зокрема в них підвищена надійність роботи, вони не потребують для живлення додаткового джерела живлення, в них виключені стандартні драйвери, до мінімуму зведено споживання енергії.

Таким чином, прикладним аспектом використання одержаного наукового результату с можливість створення конкурентоспроможних надійних безконтактних контакторів постійного струму на напругу до 1000 В та струми 100 600 А для альтернативної енергетики.

Ключові слова - безконтактний двонапрямний контактор постійного струму, комутуючий конденсатор, комутуючий тиристор, силовий напівпровідниковий ключ, альтернативна енергетика 